DOI 10.14746/ssp.2020.2.9

\author{
ks. Rafał LEŚNICZAK
}

Uniwersytet Kardynała Stefana Wyszyńskiego w Warszawie

ORCID: 0000-0003-0099-4327

\title{
Czy tygodnik katolicki ,Niedziela” poparł Prawo i Sprawiedliwość w kampanii parlamentarnej w 2019 r? Studium medioznawcze
}

Streszczenie: Celem pracy jest weryfikacja, czy tygodnik katolicki „Niedziela”, zaangażował się w kampanię parlamentarną w Polsce w 2019 r. jako uczestnik procesu komunikowania politycznego. Podstawową metodą badawczą jest ilościowa i jakościowa analiza zawartości. Pomocniczo wykorzystano także metodę analizy i syntezy oraz analizę kontekstu dyskursu prasowego. Tygodnik katolicki był czasopismem wspierającym PiS. Na jego łamach wypowiadali się politycy prawicy, których wypowiedzi były przyjmowane przez redakcję „Niedzieli” z aprobatą i życzliwością. Nieudzielenie w dyskursie politycznym głosu politykom opozycji dowodzi stronniczości tygodnika i wyeksponowania ,jedynego, słusznego" kierunku prowadzenia polityki zagranicznej, gospodarczej czy historycznej, tzn. zaproponowanego przez Prawo i Sprawiedliwość.

Słowa kluczowe: tygodnik katolicki „Niedziela”, Prawo i Sprawiedliwość, kampania parlamentarna, komunikowanie polityczne

\section{Wprowadzenie i metodologia badań}

ktywność polityczno-społeczna Kościoła katolickiego w Polsce po
1989 r. jest przedmiotem wielu analiz medioznawczych i politolo-
gicznych (Kowalczyk, 2012; Guzek, 2019, s. 123-165). Komunikowa-
nie polityczne polskich katolickich hierarchów na przestrzeni 30 lat od
upadku komunizmu ewoluowało od wyraźnego ich politycznego zaanga-
żowania na rzecz ugrupowań prawicowych do zdystansowanej postawy
Konferencji Episkopatu Polski, która, na poziomie wysyłanych komuni-
katów instytucjonalnych, potwierdzała respektowanie katolickiej nauki
społecznej oraz konstytucyjnych zasad autonomii i niezależności Kościo-
ła i państwa (Nosowski, 2018; Mariański, 2017; Nosowski, 2013; Dyda,
2016). Jeśli jednak przyjąć, że media katolickie są alternatywnym wyra- 
zicielem stanowiska instytucji eklezjalnej w kwestiach politycznych, to należy wyeksponować ich zaangażowanie w komunikowanie polityczne oraz poparcie udzielone przez nie ugrupowaniom prawicowym w okresie po upadku muru berlińskiego. Dotychczasowe analizy kampanii parlamentarnych i prezydenckich w Polsce po 1989 r. dowiodły, że tygodnik „Niedziela” jest medium katolickim zaangażowanym w ww. procesy political communication (Leśniczak, 2017; Wrześniewska, 2017; Leśniczak, 2018; Dzierżyńska-Mielczarek, 2016, s. 136-141).

Politolodzy dostrzegają wyraźną polaryzację polskiej sceny politycznej po 2005 r. (Kolczyński, 2017, s. 33) oraz odnotowują w agendzie politycznej 2019 roku obecność kwestii dotyczących Kościoła katolickiego, które zostały wykorzystane w kampanii wyborczej (m.in. temat nadużyć niektórych duchownych katolickich wobec małoletnich i inne grzechy duchownych, co zostało wyeksponowane w filmach Tylko nie mów nikomu i Kler; wystąpienie Leszka Jażdżewskiego 3.05.2019 na Uniwersytecie Warszawskim, będące krytyką Kościoła katolickiego; stanowisko abp. Jędraszewskiego wobec parad równości promujących ideologię LGBT) (Leśniczak, 2019; Duda, 2019b; Leśniczak, 2020; Klauziński, Chrzczonowicz, 2019).

W podjętych badaniach dokonano weryfikacji, czy tygodnik katolicki „Niedziela”, zaangażował się w kampanię parlamentarną jako uczestnik procesu komunikowania politycznego. Materiał badawczy stanowiły te teksty prasowe zamieszczone na ogólnopolskich stronach analizowanego tytułu prasowego, które odnosiły się do parlamentarnej kampanii wyborczej w Polsce w 2019 r. W analizie pominięto krótkie gatunki informacyjne, np. wzmianki, notatki, zapowiedzi, przegląd prasy, natomiast uwzględniono zasadniczo publikacje o charakterze publicystycznym. Publicystyka w odróżnieniu od informacji interpretuje rzeczywistość, przedstawia ją z subiektywnego i autorskiego punktu widzenia, celem wywołania u odbiorcy określonej reakcji (Kasiak, 2015, s. 85). Gatunki publicystyczne stanowią rozszerzenie lub uzupełnienie informacji, ich autorska perspektywa eksponuje światopogląd i hierarchię wartości nadawcy przekazu (Bauer, 2000, s. 157-158). Jak zauważa Zbigniew Bauer (Ibidem, s. 164), publicystyka nie powinna jednak charakteryzować się skrajnym subiektywizowaniem czy też jednostronnym i ideologicznym zaangażowaniem autora w opisywany problem. Innego zdania są niektórzy dziennikarze-publicyści, jak Renata Kim czy Michał Kacewicz, którzy cenią publicystykę zaangażowaną po jednej ze stron sporu politycznego czy konfliktu ideologicznego, publicystykę ,,pełną pasji, przewrotną, stawiającą ryzykowne tezy" (Kasiak, 2015, s. 90). Można za- 
tem przyjąć, że wybór do analizy tekstów publicystycznych „Niedzieli” zapewnia wyrazistość stanowisk ideologicznych i politycznych autorów publikacji, jak również całej linii redakcyjnej tygodnika katolickiego.

Zakres czasowy analizy objął okres od 6.08.2019, tj. dnia Postanowienia Prezydenta Rzeczypospolitej Polskiej w sprawie zarzadzenia wyborów do Sejmu i Senatu Rzeczypospolitej Polskiej (Postanowienie Prezydenta Rzeczypospolitej Polskiej z dnia 6 sierpnia 2019 r...) do dnia elekcji wyborczej, tj. do 13.10.2019. Analizą objęto łącznie 10 edycji tygodnika, od nr 32 (2019) do nr 41 (2019). Do próby badawczej zostały włączone te teksty, które podjęły zagadnienia polityczno-społeczne i w których zostały wyeksponowane poglądy polityków partii Prawo i Sprawiedliwość oraz partii opozycyjnych. Uwzględniono również te publikacje prasowe, które dotyczyły osoby i aktywności politycznej prezydenta Andrzeja Dudy. Został on potraktowany jako wspierający działania rządu Szydło i Morawieckiego i jako osoba wywodząca się z obozu „dobrej zmiany” (Kotras, 2018, s. 149). Ogółem kryteria badań spełniło 40 tekstów prasowych opublikowanych w ogólnopolskich edycjach wersji drukowanej „Niedzieli”.

Zakres temporalny analizy jest częścią kampanii permanentnej (Zaręba, 2016; Garlicki, 2010; Biskup, 2012) obejmującej kampanię europarlamentarną, związaną z wyborami posłów do Parlamentu Europejskiego w dniu 26.05.2019 (Postanowienie Prezydenta Rzeczypospolitej Polskiej z dnia 25 lutego 2019 r...), oraz kampanię prezydencką związaną z wyborami zaplanowanymi na miesiące letnie 2020 r. Przyjęto założenie, że okres 6.08.2019-13.10.2019 jest wystarczającą próbą reprezentatywną, aby odpowiedzieć na pytanie badawcze, czy tygodnik katolicki „Niedziela" wsparł Prawo i Sprawiedliwość w końcowym, decydującym etapie kampanii parlamentarnej $2019 \mathrm{r}$.

Podstawową metodą badawczą jest ilościowa i jakościowa analiza zawartości. Pomocniczo wykorzystano także metodę analizy i syntezy oraz analizę kontekstu dyskursu prasowego.

Posłużono się specjalnie skonstruowanym kluczem kategoryzacyjnym, w którym wyodrębniono następujące cechy badawcze: „DZIAŁANIA RZĄDU W LATACH 2015-2019”; „DZIAŁANIA PREZYDENTA RP ANDRZEJA DUDY”, „DZIAŁANIA POLITYCZNE OPOZYCJI”, „KAMPANIA i PROGRAM WYBORCZY PiS”; „WIARA I WARTOŚCI CHRZEŚCIJAŃSKIE". Kategorie w ramach badanej cechy mają charakter rozłączny i publikacja może zostać przyporządkowana do jednej tylko kategorii w ramach badanej cechy. 
Klucz kategoryzacyjny wraz z cechami i kategoriami

\begin{tabular}{|c|c|}
\hline $\begin{array}{c}\text { Badana cecha } \\
\text { i definicja cechy }\end{array}$ & Kategorie i definicje w ramach badanej cechy \\
\hline 1 & 2 \\
\hline \begin{tabular}{||l|} 
DZIAŁANIA RZĄ- \\
DU W LATACH \\
2015-2019- spo- \\
sób prezentacji na \\
łamach „Niedzieli” \\
działań rządu Beaty \\
Szydło i Mateusza \\
Morawieckiego \\
i ich konsekwencji \\
dla życia Polaków
\end{tabular} & $\begin{array}{l}\text { 1) aprobata - autorzy publikacji oceniaja } \\
\text { i gospodarcze rządu jako trafne, odpow } \\
\text { rozwoju Polski i dla poprawy życia Pola } \\
\text { programu ,500 plus”, legitymizacja refo } \\
\text { 2) dezaprobata - autorzy publikacji oceniaj } \\
\text { i gospodarcze rządu jako błędne, skutk } \\
\text { konsekwencjami politycznymi i ekonom } \\
\text { 3) ambiwalentna - autorzy publikacji oceni } \\
\text { ne i gospodarcze rządu w niejednoznacz } \\
\text { zując ich trafność, racjonalność, jak rów } \\
\text { 4) brak oceny - autorzy publikacji nie oce } \\
\text { nych i gospodarczych rządu. }\end{array}$ \\
\hline \begin{tabular}{|l} 
DZIAŁANIA \\
PREZYDENTA \\
RP ANDRZEJA \\
DUDY - sposób \\
prezentacji na \\
łamach „Niedzieli” \\
działan Prezydenta \\
RP Andrzeja Dudy \\
i ich konsekwencji \\
dla życia Polaków
\end{tabular} & $\begin{array}{l}\text { kacji oceniają działania Prezydenta RP } \\
\text { ie i korzystne dla rozwoju Polski i dla } \\
\text { ublikacji oceniają działania Prezydenta } \\
\text { jjące niekorzystnymi konsekwencjami } \\
\text { cznymi dla Polaków; } \\
\text { y publikacji oceniają działania Prezy- } \\
\text { aczny sposób, tzn. wskazując ich traf- } \\
\text { cównież błędy; } \\
\text { blikacji nie oceniają działań Prezyden- }\end{array}$ \\
\hline \begin{tabular}{|l} 
DZIAŁANIA \\
POLITYCZNE \\
OPOZYCJI - spo- \\
sób prezentacji na \\
łamach „Niedzieli” \\
działań ugrupowań \\
opozycyjnych \\
(wszystkich partii \\
politycznych poza \\
PiS)
\end{tabular} & $\begin{array}{l}\text { 1) aprobata - autorzy publikacji oceniają działania polityczne } \\
\text { i gospodarcze opozycji jako trafne, odpowiednie i korzystne } \\
\text { dla rozwoju Polski i dla poprawy życia Polaków; } \\
\text { 2) dezaprobata - autorzy publikacji oceniają działania polityczne } \\
\text { i gospodarcze opozycji jako błędne, skutkujące niekorzystnymi } \\
\text { konsekwencjami politycznymi i ekonomicznymi dla Polaków; } \\
\text { 3) ambiwalentna - autorzy publikacji oceniają działania politycz- } \\
\text { ne opozycji w niejednoznaczny sposób, tzn. wskazując ich traf- } \\
\text { ność, racjonalność, jak również błędy; } \\
\text { 4) brak oceny - autorzy publikacji nie oceniają działań politycz- } \\
\text { nych opozycji. }\end{array}$ \\
\hline \begin{tabular}{|l|} 
KAMPANIA \\
i PROGRAM \\
WYBORCZY PiS - \\
sposób prezentacji \\
na łamach „Nie- \\
dzieli” kampanii \\
i programu wybor- \\
czego Prawa
\end{tabular} & $\begin{array}{l}\text { 1) aprobata - autorzy publikacji oceniają kampanię i program wy- } \\
\text { borczy PiS jako właściwe i korzystne dla Polski i Polaków (np. } \\
\text { przyczyniające się do wzrostu gospodarczego, wzrostu zamoż- } \\
\text { ności społeczeństwa); } \\
\text { 2) dezaprobata - autorzy publikacji oceniają kampanię i program } \\
\text { wyborczy PiS jako niekorzystne dla Polski i Polaków (np. skut- } \\
\text { kujące spowolnieniem gospodarczym, zubożeniem społeczeń- } \\
\text { stwa); }\end{array}$ \\
\hline
\end{tabular}




\begin{tabular}{|c|c|}
\hline 1 & 2 \\
\hline $\begin{array}{l}\text { i Sprawiedliwości } \\
\text { w } 2019 \text { r. }\end{array}$ & $\begin{array}{l}\text { 3) ambiwalentna - autorzy publikacji oceniają kampanię i pro- } \\
\text { gram wyborczy PiS w niejednoznaczny sposób, tzn. wskazując } \\
\text { ich trafność, racjonalność, jak również błędy; } \\
\text { 4) brak oceny - autorzy publikacji nie oceniają kampanii i progra- } \\
\text { mu wyborczego PiS. }\end{array}$ \\
\hline \begin{tabular}{|l} 
WIARA I WARTO- \\
ŚCI CHRZEŚCI- \\
JAŃSKIE - sposób \\
prezentacji na \\
łamach „Niedzieli” \\
deklarowanych \\
przez Prawo \\
i Sprawiedliwość \\
oraz Prezydenta \\
RP Andrzeja Dudę \\
poglądów na temat \\
wiary i wartości \\
chrześcijańskich.
\end{tabular} & $\begin{array}{l}\text { 1) zgodność - poglądy prezentowane są jako zgodne z Magiste- } \\
\text { rium Kościoła; } \\
\text { 2) niezgodność - poglądy prezentowane są jako niezgodne z Ma- } \\
\text { gisterium Kościoła; } \\
\text { 3) ambiwalentność - poglądy prezentowane są jako częściowo } \\
\text { zgodne i częściowo niezgodne z Magisterium Kościoła; } \\
\text { 4) brak oceny - autorzy publikacji nie dokonują oceny poglądów } \\
\text { PiS w kwestiach wiary i wartości. }\end{array}$ \\
\hline
\end{tabular}

Źródło: Opracowanie własne.

W kampanii parlamentarnej 2019 r. w Polsce komitet wyborczy Prawo i Sprawiedliwość ubiegał się ponownie o zwycięstwo wyborcze, by kontynuować sprawowanie rządów (Flis, Michalak, 2019, s. 74-75). Ocena osoby i działań prezydenta RP Andrzeja Dudy, mającego poparcie polityczne obozu „dobrej zmiany” (Szczegóła, Kwiatkowski, 2017), jest również istotnym czynnikiem oceny stopnia polityzacji „Niedzieli”. Potraktowano rekomendację udzieloną Andrzejowi Dudzie przez tygodnik jako alternatywny sposób poparcia polskiej prawicy, a więc także i PiS, z której środowiska Prezydent RP się wywodzi. Nieobojętnym w odpowiedzi na pytanie o ewentualne wsparcie kampanii parlamentarnej PiS przez czasopismo katolickie, jest wiedza na temat oceny działań innych partii politycznych, m.in. Platformy Obywatelskiej. Liderzy Prawa i Sprawiedliwości podczas sprawowania rządów i podczas kampanii wyborczej, deklarowali zbieżne z Magisterium Kościoła poglądy na temat fundamentalnych wartości, na temat rodziny, roli religii i Kościoła katolickiego w społeczeństwie (KW Prawo i Sprawiedliwość). Taka postawa ideologiczna PiS wpisuje się w ich permanentną postawę wobec Kościoła katolickiego po 1989 r. (Kowalczyk, 2015, s. 170-175).

Sformułowano następujące hipotezy kierunkowe HK1-HK5:

HK1: Autorzy publikacji „Niedzieli” oceniają działania polityczne i gospodarcze rządu Beaty Szydło i Mateusza Morawieckiego w latach 
2015-2019 jako trafne, odpowiednie i korzystne dla rozwoju Polski i dla poprawy życia Polaków.

HK2: Autorzy publikacji „Niedzieli” oceniają działania Prezydenta RP

jako trafne, odpowiednie i korzystne dla rozwoju Polski i dla poprawy życia Polaków.

HK3: Autorzy publikacji „Niedzieli” oceniają działania polityczne opozycji jako błędne, skutkujące niekorzystnymi konsekwencjami politycznymi i ekonomicznymi dla Polaków.

HK4: Autorzy publikacji „Niedzieli” oceniają kampanię i program wyborczy PiS w 2019 r. jako właściwe i korzystne dla Polski i Polaków. HK5: Poglądy PiS i Prezydenta RP na temat wiary i wartości chrześcijańskich prezentowane są na łamach „Niedzieli” jako zgodne z Magisterium Kościoła.

Zaś hipoteza badawcza przyjęła następującą formę:

Autorzy publikacji „Niedzieli” oceniają działania polityczne i gospodarcze rządu Beaty Szydło i Mateusza Morawieckiego oraz działania Prezydenta RP Andrzeja Dudy w latach 2015-2019 jako trafne, odpowiednie i korzystne dla rozwoju Polski i dla poprawy życia Polaków. Z kolei działania polityczne opozycji potraktowano w tygodniku katolickim jako błędne, skutkujące niekorzystnymi konsekwencjami politycznymi i ekonomicznymi dla Polaków. W tekstach prasowych „Niedzieli” kampanię i program wyborczy PiS w 2019 r. zaprezentowano jako właściwe i korzystne dla Polski i Polaków. Poglądy Prawa i Sprawiedliwości oraz Prezydenta RP Andrzeja Dudy na temat wiary i wartości chrześcijańskich zademonstrowano jako zgodne z Magisterium Kościoła.

\section{Wyniki ilościowej i jakościowej analizy zawartości}

Tabele 2-6 prezentują liczbę publikacji zaklasyfikowanych do poszczególnych kategorii w ramach badanych cech.

Tabela 2 .

DZIAŁANIA RZĄDU W LATACH 2015-2019 w tekstach prasowych „Niedzieli” - liczba publikacji przyporządkowana do danej kategorii

\begin{tabular}{||c|c|c|c|c||}
\hline $\begin{array}{c}\text { Tytul prasowy / } \\
\text { kategoria }\end{array}$ & Aprobata & Dezaprobata & Ambiwalentna & Brak oceny \\
\hline „Niedziela” & 19 & 0 & 0 & 21 \\
\hline \hline
\end{tabular}

Źródło: Opracowanie własne. 
Tabela 3

DZIAŁANIA PREZYDENTA RP ANDRZEJA DUDY w tekstach prasowych ,Niedzieli” - liczba publikacji przyporządkowana do danej kategorii

\begin{tabular}{||c|c|c|c|c|}
\hline $\begin{array}{c}\text { Tytul prasowy / } \\
\text { kategoria }\end{array}$ & Aprobata & Dezaprobata & Ambiwalentna & Brak oceny \\
\hline „Niedziela” & 7 & 0 & 0 & 33 \\
\hline
\end{tabular}

Źródło: Opracowanie własne.

Tabela 4

DZIAŁANIA POLITYCZNE OPOZYCJI w tekstach prasowych ,Niedzieli" - liczba publikacji przyporządkowana do danej kategorii

\begin{tabular}{||c|c|c|c|c|}
\hline $\begin{array}{c}\text { Tytul prasowy / } \\
\text { kategoria }\end{array}$ & Aprobata & Dezaprobata & Ambiwalentna & Brak oceny \\
\hline „Niedziela” & 0 & 10 & 0 & 30 \\
\hline \hline
\end{tabular}

Źródło: Opracowanie własne.

Tabela 5

KAMPANIA i PROGRAM WYBORCZY PiS w tekstach prasowych ,Niedzieli" - liczba publikacji przyporządkowana do danej kategorii

\begin{tabular}{||c|c|c|c|c|}
\hline $\begin{array}{c}\text { Tytul prasowy / } \\
\text { kategoria }\end{array}$ & Aprobata & Dezaprobata & Ambiwalentna & Brak oceny \\
\hline „Niedziela” & 18 & 0 & 0 & 22 \\
\hline \hline
\end{tabular}

Źródło: Opracowanie własne.

Tabela 6

WIARA I WARTOŚCI CHRZEŚCIJAŃSKIE w tekstach prasowych ,Niedzieli" - liczba publikacji przyporządkowana do danej kategorii

\begin{tabular}{||c|c|c|c|c||}
\hline $\begin{array}{c}\text { Tytul prasowy / } \\
\text { kategoria }\end{array}$ & Zgodność & Niezgodność & $\begin{array}{c}\text { Ambiwalent- } \\
\text { ność }\end{array}$ & Brak oceny \\
\hline „Niedziela” & 18 & 1 & 0 & 21 \\
\hline \hline
\end{tabular}

Źródło: Opracowanie własne.

Liczba publikacji zaklasyfikowanych do poszczególnych kategorii w ramach badanych cech dowodzi jednostronności przekazu i wyraźnego poparcia przez tygodnik „Niedziela” partii politycznej Prawo i Sprawiedliwość podczas kampanii parlamentarnej w 2019 r. W badanej cesze „DZIAŁANIA RZĄDU W LATACH 2015-2019” odnotowano 19 publikacji przyporządkowanych do kategorii ,aprobata”, 
żadna natomiast nie została zaliczona do kategorii „dezaprobata” bądź „ambiwalentna”. Analogiczną sytuację odnotowano w kategoriach „DZIAŁANIA PREZYDENTA RP ANDRZEJA DUDY” (liczba publikacji należących do kategorii ,aprobata” - 7, do kategorii „,dezaprobata” - 0, do kategorii ,ambiwalentna” - 0) oraz „KAMPANIA i PROGRAM WYBORCZY PiS” (liczba publikacji należących do kategorii „aprobata”-18, do kategorii „dezaprobata” - 0, do kategorii ,ambiwalentna" - 0). Działania polityczne opozycji spotkały się z dezaprobatą wyrażoną w 10 publikacjach, przy braku jakiegokolwiek jej poparcia przez autorów publikacji tygodnika katolickiego. Analiza ilościowa eksponuje, że poglądy PiS i Prezydenta RP na temat wiary i wartości chrześcijańskich zaprezentowane zostały na łamach „Niedzieli” jako zgodne z Magisterium Kościoła (liczba publikacji należących do kategorii „zgodność” - 18, do kategorii „niezgodność” - 1, do kategorii „ambiwalentność”-0).

\section{Obraz działań rządu w latach 2015-2019 na lamach „Niedzieli” jest pozytywny}

Tygodnik zaprezentował zagadnienie Forum Ekonomicznego odbywającego się w dniach 3-5.09.2019 w Krynicy-Zdroju, jako miejsce spotkania elit Europy Środkowo-Wschodniej, debatujących nad kwestiami biznesu i zarządzania, inwestycji i rozwoju, Europy i świata, makroekonomii, nowej gospodarki, państwa i reform, społeczeństwa, a także polityki międzynarodowej, bezpieczeństwa, energetyki i innowacji. Wymieniono wśród uczestników liczną reprezentację polityków Prawa i Sprawiedliwości: Jerzego Kwiecińskiego - ministra inwestycji i rozwoju, Witolda Bańkę - ministra sportu i turystyki, Andrzeja Adamczyka - ministra infrastruktury, Dariusza Piontkowskiego - ministra edukacji narodowej, Andrzeja Bittela - sekretarza stanu w Ministerstwie Infrastruktury (Czy Europa przemówi wspólnym głosem?). Autorzy „Niedzieli” zauważają, że Forum stanowi także promocję organizacji pozarządowych, np. Caritas Polska. Tygodnik katolicki zwrócił uwagę, że w 2019 roku ,,prestiżową nagrodę Człowieka Roku Forum Ekonomicznego 2018 otrzymał premier Mateusz Morawiecki - za umiejętność pogodzenia wydatków związanych z wielkimi projektami społecznymi z obniżeniem i uproszczeniem systemu podatkowego" (Cinzio, 2019). 
W publikacji Z myśla o polskich rodzinach Czesław Ryszka (2019c) chwali polskiego premiera i jego ministrów za hasło budowy „polskiej wersji państwa dobrobytu”, w którego centrum jest rodzina. Publicysta przywołał słowa Morawieckiego: „budujemy Polskę nowoczesną, rozwijającą się, skutecznie zaspokajającą potrzeby polskich rodzin, Polskę czerpiącą swe siły z kultury, historii, z wartości”. Jak zauważa Ryszka, „hattrick Kaczyńskiego”, tj. wyższe płace, wyższe emerytury oraz wyrównanie dopłat dla rolników na pełnym europejskim poziomie jest elementem budowy dobrobytu polskich rodzin:

\begin{abstract}
„Ale nie tylko o pieniądze chodzi. Ten program opiera się na wartościach, ponieważ jest prorodzinny, a to oznacza, że odrzuca się model gospodarczy Polski jako kraju niskich pensji i, co za tym idzie, niskiej wydajności. Koniec myślenia, że Polska jest rezerwuarem taniej siły roboczej. Polacy mają konkurować kompetencjami, wiedzą i doświadczeniem" (Ibidem; por. także: Morawiecki, 2019b).
\end{abstract}

„Niedziela” dedykuje obszerny materiał zasadności podjętej reformy szkolnictwa przez ministra Dariusza Piontkowskiego, pozytywnym efektom przeobrażeń dokonujących się w obszarze edukacji, podwyżce płac nauczycieli, manipulacjom przeciwników reformy (Piontkowski, 2019; por. także Michałek, 2019).

W artykule To nie jest artykuł pierwszej potrzeby można odnaleźć komentarz dotyczący pozytywnych następstw wprowadzonych w styczniu 2018 r. przez rząd Morawieckiego zmian w ustawie o wychowaniu w trzeźwości i przeciwdziałaniu alkoholizmowi (akw, 2019).

„Niedziela" przeprowadziła na swoich łamach wywiad z Anną Gembicką (2019), podsekretarzem stanu w Ministerstwie Inwestycji i Rozwoju, prezentując w korzystnym świetle działania polityków polskiej prawicy zaangażowanych w kwestie wspierania przedsiębiorczości i wyrównywania szans (Por. także Obajtek, 2019; Adamczyk, 2019). Z kolei na temat osiągnięć polskiego rządu dotyczących pomocy Polakom na Wschodzie można przeczytać w wywiadzie zatytułowanym Polacy ze Wschodu wracaja do ojczyzny, którego respondentem była Anna Schmidt-Rodziewicz (2019), sekretarz stanu w Kancelarii Prezesa Rady Ministrów i pełnomocnik Premiera ds. dialogu międzynarodowego. W ww. tekstach dostrzegalna jest życzliwość pytających, którzy z aprobatą przyjmują odpowiedzi na zadane pytania. 


\section{Sylwetka i dzialania Prezydenta RP zostały przedstawione wylącznie w korzystny sposób}

Jak zauważa publicysta „Niedzieli” Czesław Ryszka (2019a), Andrzej Duda jest „prezydentem niezależnym”, niezależnym od Prawa i Sprawiedliwości, ponieważ ,zawetował ważne dla tego ugrupowania ustawy o KRS i Sądzie Najwyższym, a 8 ustaw skierował do Trybunału Konstytucyjnego". Tygodnik katolicki przypisuje Dudzie m.in. sukcesy w polityce zagranicznej, jego kapitałem jest bardzo duże zaufanie społeczne, jest on inicjatorem ważnych projektów zmian w prawie, np. przywrócenia wieku emerytalnego, podwyższenia kwoty wolnej od podatku, projektów dotyczących pomocy frankowiczom (Ibidem; jk, 2019).

Jan Żaryn (2019), ceniony historyk i działacz społeczny, z uznaniem odniósł się do decyzji Prezydenta RP dotyczącej objęcia swoim patronatem uroczystości upamiętniających 75 . rocznicę powstania Brygady Świętokrzyskiej Narodowych Sił Zbrojnych.

W publikacji Marty Fortuny-Sudor Wolni, niezłomni, wierni (2019) Andrzej Duda zostaje zaprezentowany jako patriota i człowiek wierzący. Kontekst publikacji stanowią obchody 100-lecia Związku Podhalan, podczas których, po odprawionej mszy św. przez abp. Jędraszewskiego, Prezydent RP nadał Ordery Odrodzenia Polski współtwórcom i działaczom związku, Feliksowi Gwiżdżowi i Jakubowi Zachemskiemu. Słowa laudacji Dudy wypowiedziane pod adresem górali mają dowodzić jego przywiązania do wiary i wartości chrześcijańskich:

„W przemówieniu, nagradzanym wielokrotnie brawami, Andrzej Duda podkreślał m.in. przywiązanie górali do wolności. Chwalił ich za niezłomność i upór. I zauważył: - W tym wszystkim ogromną rolę odgrywała wiara. I poddanie się Matce Najświętszej, Gaździnie Podhala... Prezydent podkreślił też szczególną cechę górali w podtrzymywaniu tradycji i dokonywaniu właściwych wyborów z tego, co niesie nowoczesność" (Ibidem).

Andrzej Duda, w kontekście uroczystości 80. rocznicy wybuchu II wojny światowej, zostaje przedstawiony jako mąż stanu, który potrafi nie tylko odwoływać się do historii, ale również dostrzegać współczesne zagrożenia demokracji i potencjalne konflikty zbrojne. Prezydent odwołał się do agresywnej polityki Federacji Rosyjskiej:

„Nie można, nie wolno przechodzić do porządku dziennego nad takimi działaniami. Muszą być sankcje, muszą być podejmowane 
zdecydowane kroki, musi być widać, że każda militarna agresja spotka się z absolutnie stanowczą, zdecydowaną, potężną odpowiedzią. [...] Wystąpienie prezydenta RP było najmocniejszym akcentem obchodów 80. rocznicy wybuchu II wojny światowej. Andrzej Duda przestrzegł przed popełnieniem błędów z przeszłości i przypomniał zdradę Polski przez sojuszników w 1939 r., ale także wcześniejsze błędy aliantów, sprzed wybuchu wojny" (Stelmasiak, 2019b).

\section{Tygodnik negatywnie odniósł się do działań opozycji}

„Niedziela" krytycznie oceniła, jako niestosowną, propozycję obchodów 80. rocznicy wybuchu II wojny światowej autorstwa prezydent Gdańska, Aleksandry Dulkiewicz z Platformy Obywatelskiej, która miała przyjąć formę ,radosnego pochodu” oraz tańców. Formę tę uznał tygodnik za nieelegancką i zarzucił Dulkiewicz ignorancję i brak wiedzy historycznej dotyczącej form okupacji niemieckiej:

„Chce Pani urządzać wesołości i tańce z odwiecznym wrogiem Polski na grobach i cierpieniu milionów Polaków? [...] Nie wie Pani, co to znaczy walenie kolbami w drzwi i zabieranie ludzi - dobrze, jeśli tylko do pracy w Niemczech, ale przecież wywożono ich także do obozów, wieszano, głodzono, bito, poniżano, mordowano w najokropniejszy sposób" (Kubicka, 2019).

W kontekście dyskusji politycznej na temat projektu „Zatrzymaj aborcję” publicyści „Niedzieli” podkreślają zasługi Kai Godek oraz KW Prawicy Marka Jurka dla ochrony życia nienarodzonych oraz wypowiedzenia konwencji stambulskiej. Jednocześnie poddają krytyce osoby odpowiedzialne za „utrącenie” projektu, tj. byłego prezydenta Bronisława Komorowskiego, Donalda Tuska, liberalne media, ale także „formację deklarującą konserwatywne poglądy”, dla której kwestia ochrony życia była niewygodna (Stelmasiak, 2019c).

W kontekście spraw ekonomiczno-gospodarczych, w niekorzystnym kontekście zaprezentowano na łamach „Niedzieli” działania PO i PSL, choćby dotyczące zaniedbań małych miast i miejscowości (Gembicka, 2019, s. 26). Na tle programów prospołecznych PiS dokonano krytyki opozycji i rządów PO-PSL:

„Nie tylko została ujawniona skala kradzieży z budżetu państwa, ale wprowadzono mechanizmy kontroli, które skutecznie zablo- 
kowały działalność mafii VAT i paliwowych. Nie znamy tylko odpowiedzi na pytanie: Dlaczego przez tyle lat nikt nie zajmował się tą przestępczością, która rozwijała się na oczach polityków i urzędników? Rządy PO-PSL zamiast pozszywać dziurawy worek budżetu państwa, zaczęły podnosić podatki” (Stelmasiak, 2019a, s. 14).

Prezes PKN Orlen, Daniel Obajtek zauważa, że w czasie rządów Platformy Obywatelskiej, mafia paliwowa przyczyniła się do ogromnych strat finansowych państwowej spółki:

„Bardzo dużo paliwa ginęło w niewyjaśnionych okolicznościach. Mieliśmy straty z powodu nawiercania rurociągów i spuszczania z nich paliwa. Kradzieże zdarzały się też na cysternach. [...] Cysterny z nielegalnym paliwem jeździły po całym kraju, nawet tam, gdzie nie było dróg. Paliwo migrowało, ale nikt z tym nic nie robił. Słynne słowa ministra Sienkiewicza o stanie naszego kraju były prawdziwe, bo tak to właśnie wyglądało. Polska była państwem czysto teoretycznym i tak samo teoretyczny był biznes państwowych spółek. Na szczęście to się radykalnie zmieniło, odkąd rządzi PiS” (Obajtek, 2019, s. 37).

\section{Autorzy publikacji „Niedzieli”, do których należą także politycy prawicy, oceniają kampanię i program wyborczy PiS jako wlaściwe i korzystne dla Polski i Polaków}

Publikacja Bilans czterech lat rządu z aprobatą wskazuje osiągnięcia rządów Szydło i Morawieckiego jako korzystne dla Polski. Do nich należą m.in. programy prospołeczne, prorodzinne i prorozwojowe, zwiększenie wpływów do budżetu o $100 \mathrm{mld}$ zł, uszczelnienie systemu podatkowego, wzrost gospodarczy. Do trudności i kłopotów rządu PiS zaliczono przedłużający się kryzys w służbie zdrowia, brak sukcesu sztandarowego programu „Mieszkanie+”, spór o reformę wymiaru sprawiedliwości, historyczny spór z Izraelem i organizacjami żydowskimi (Stelmasiak, 2019a).

W artykule Od tego zależy przyszłość Polski tygodnik prezentuje stanowisko Jana Jackowskiego, w kwestii spadku dzietności w Polsce. Wypowiedź polityka prawicy wyraża zatroskanie o przyszłość Polski, oraz jest pozytywną oceną działań rządu PiS w obszarze polityki pronatalistycznej: 
„W związku z raportem skierowałem do Premiera RP interpelację senatorską, w której proszę o informację, jakie wnioski wyciągnął z tego dokumentu rząd i czy zostanie podjęta korekta polityki rodzinnej, aby nakierować ją bardziej pronatalistycznie. [...] To prawda, że Polska pod rządami PiS nadrabia ogromne zaniedbania w polityce rodzinnej, lecz polski rząd absolutnie nie może spocząć na laurach. Potrzebna jest lepsza polityka rodzinna. Od tego zależy przyszłość Polski” (Jackowski, 2019).

Zarówno Prezydent RP jak i Prawo i Sprawiedliwość zostają zaprezentowani w „Niedzieli” jako strażnicy wiary, patriotyzmu i wartości chrześcijańskich

80. rocznica wybuchu drugiej wojny światowej była okazją dla redaktorów „Niedzieli”, aby zamieścić na jej łamach okolicznościowe odezwy premiera RP, Mateusza Morawieckiego oraz Prezydenta RP, Andrzeja Dudy, którzy odwołali się nie tylko do bolesnych kart II wojny światowej, ale wskazali na doniosłość podstawowych wartości chrześcijańskich i praw człowieka w budowaniu dojrzałej demokracji (Duda, 2019a; Morawiecki, 2019a). Morawiecki wyeksponował współczesne sukcesy polityczne i gospodarcze Polski, które domyślnie zostają przypisane rządom PiS:

„Dziś Polska jest globalnym liderem wzrostu gospodarczego oraz jednym z najlepszych dowodów na sukces rozszerzenia NATO i Unii Europejskiej. Polska pokazuje, że można łączyć solidaryzm społeczny z budową konkurencyjnej i innowacyjnej gospodarki dzięki tworzeniu nowoczesnego systemu podatkowego, dostosowanego do wyzwań XXI wieku" (Morawiecki, 2019a, s. 11).

Z kolei Duda podkreślił zaangażowanie Polski w walkę o poszanowanie praw człowieka i narodów:

„W osiemdziesiąt lat od wybuchu II wojny światowej społeczność państw wolnego świata musi trwać zjednoczona wokół celu, którym jest budowa trwałego ładu bezpieczeństwa, opartego na realnym poszanowaniu praw człowieka oraz prawa narodów. Pragnę zapewnić, że Polska, pamiętając o swoich doświadczeniach wojennych, jest i pozostanie zaangażowana w to dzieło z niewzruszoną konsekwencją i stanowczością" (Duda, 2019a).

W wywiadzie Zależy mi na silnej $i$ wolnej Polsce, Morawiecki podkreśla doniosłość wiary i wartości we własnym życiu oraz istotność pontyfikatu Jana Pawła II: 
„Chrześcijaństwo niesie ze sobą taki zasób uniwersalnych wartości, na których można budować prawdziwą wspólnotę. [...] Kiedy Karol Wojtyła zasiadł na tronie papieskim, miałem 10 lat. Jego pontyfikat towarzyszył mojemu dorastaniu i dojrzewaniu. Dlatego też czuję się członkiem pokolenia Polaków, którzy Papieżowi Polakowi wiele zawdzięczają intelektualnie i duchowo" (Morawiecki, 2019b, s. 11-12).

Jarosław Grabowski, redaktor naczelny „Niedzieli”, pozycjonuje Dudę i Morawieckiego wśród kustoszy polskiej pamięci historycznej, obok takich autorów jak Michał Kleiber czy Marco Patricelli (Grabowski, 2019b).

„Niedziela” zajęła wyraźne stanowisko dotyczące eksponowania wiary i wartości przez polityków katolickich, jednocześnie wskazując wpływ trzech wielkich areopagów na człowieka (uniwersytety, parlamenty, media), które w skuteczny sposób mogą promować tzw. neutralność światopoglądową:

„[...] polityk katolik powinien się utożsamiać ze swoją wiarą, nie może uniknąć prezentowania swoich osobistych przekonań, powinien promować swoje poglądy, gdzie się tylko da - podobnie zresztą jak czynią to nieustannie ateiści i agnostycy" (Ryszka, 2019b).

„Niedziela” udzieliła aprobaty stanowisku przewodniczącego Parlamentarnego Zespołu ds. Oszacowania Wysokości Odszkodowań Należnych Polsce od Niemiec, Arkadiuszowi Mularczykowi, który wskazał straty materialne i ludzkie czasów niemieckiej okupacji oraz wyjaśnił konsekwencje ekonomiczne II wojny światowej i okupacji sowieckiej dla przyszłych losów Polski. Prawo i Sprawiedliwość zostało przedstawione jako ugrupowanie polityczne słusznie domagające się sprawiedliwości za wyrządzone Polsce szkody (Mularczyk, 2019).

Tygodnik wyeksponował również niesienie pomocy Polakom mieszkającym na Wschodzie jako rodzaj współczesnego patriotyzmu. W tym obszarze podkreślono zasługi rządu PiS:

„--Całe instrumentarium finansowe, zmiany ułatwiające przyjazd, przyspieszenie wydawania wiz repatriacyjnych oraz tworzenie ośrodków - to zmiany, które my wprowadziliśmy, w tej kadencji Sejmu" (Schmidt-Rodziewicz, 2019, s. 17).

„Niedziela” przywołuje program wyborczy PiS wraz z wypowiedziami jej polityków. W tekście Szkoła bez eksperymentów Wojciech Dud- 
kiewicz prezentuje model szkoły według Jarosława Kaczyńskiego, który odwołuje się do wartości chrześcijańskich:

„- Chcemy szkoły, która będzie kształtowała postawy - powiedział Jarosław Kaczyński. [...] Jego zdaniem, szkoła powinna uczyć, wychowywać i przygotowywać do życia - w sensie potrzebnych na co dzień umiejętności i w sferze duchowej; powinna wskazywać młodym ludziom, jak się odnajdywać w sferze kultury. Szkoła, według Kaczyńskiego, nie może być miejscem eksperymentów społecznych wymierzonych w dzieci i młodzież, tymczasem są takie plany w różnych miejscach w Polsce. Szkoła nie może też godzić w prawa rodziców do wychowania swoich dzieci, podważać fundamentu rodziny, konstrukcji społecznej, która stworzyła chrześcijańską cywilizację - najbardziej życzliwą człowiekowi ze wszystkich w dziejach świata" (Dudkiewicz, 2019).

Jedyną publikacją zaklasyfikowaną do kategorii „niezgodność” w badanej cesze „WIARA I WARTOŚCI CHRZEŚCIJAŃSKIE” należy tekst prasowy Poset na ambonie, w którym przestawiono niezgodne z katolicką nauką społeczną wykorzystanie ambony przez europosła Ryszarda Czarneckiego w kościele w Kamieńcu Wrocławskim do celów politycznych (wd, 2019).

W „Niedzieli” odnotowano także teksty prasowe prezentujące nauczanie Kościoła w kwestii obowiązku uczestnictwa katolika w życiu publicznym, w tym także obowiązek pójścia na wybory (Rozpiątkowski, 2019; Grabowski, 2019a; Wysogląd, 2019; Gadowski, 2019).

\section{Weryfikacja hipotez badawczych. Wnioski i ich interpretacja}

Przeprowadzona analiza prasoznawcza potwierdza prawdziwość hipotez kierunkowych HK1-HK5 oraz hipotezy badawczej.

Weryfikacja hipotez dowodzi, że linia redakcyjna „Niedzieli” nie zmieniła się podczas polskiej kampanii parlamentarnej w 2019 r. Tygodnik katolicki był czasopismem wspierającym Prawo i Sprawiedliwość. $\mathrm{Na}$ jego łamach wypowiadali się politycy prawicy, których wypowiedzi były przyjmowane przez redakcję „Niedzieli” z aprobatą i życzliwością. Nieudzielenie w dyskursie politycznym głosu politykom opozycji dowodzi stronniczości tygodnika i wyeksponowania ,jedynego, słusznego" kierunku prowadzenia polityki zagranicznej, gospodarczej czy historycznej, tzn. zaproponowanego przez Prawo i Sprawiedliwość. 
Zważywszy, że wydawcą tygodnika katolickiego „Niedziela” jest Kuria Metropolitalna w Częstochowie, zaś jej redaktorem naczelnym - katolicki duchowny mianowany przez arcybiskupa częstochowskiego, należy przyjąć stanowisko redakcji w kwestiach politycznych jako instytucjonalny głos Kościoła katolickiego. Należy jednak zauważyć, że autorami tekstów popierających wyraźnie Prawo i Sprawiedliwość nie są duchowni katoliccy, co jednak nie zmienia faktu, że redakcja pisma ponosi odpowiedzialność za jego treść i może skutecznie moderować dyskurs polityczny, np. zapraszając na swoje łamy polityków także innych partii politycznych niż PiS lub ich zwolenników.

Zaangażowanie „Niedzieli” w procesy komunikowania politycznego dowodzi udziału tygodnika w procesie mediatyzacji polityki. Nawiązując do badań Zbigniewa Oniszczuka, można stwierdzić, że katolicki periodyk organizował i prowadził dyskurs publiczny; kontrolował dostęp do informacji, poglądów i interesów politycznych obecnych w przekazach medialnych wśród swoich czytelników; dowiódł również politycznego i społecznego znaczenia mediów katolickich dla władzy politycznej (Oniszczuk, 2011, s. 14-15).

\section{Bibliografia}

Adamczyk A. (2019), Polska jest liderem inwestycji, rozm. przeprowadził A. Stelmasiak, „Niedziela” z dnia 6.10.2019 r.

Adamski A. (2019), Zaszczyt, na który muszę zastugiwać, „Niedziela” z dnia 13.10.2019 r.

akw. (2019), To nie jest artykut pierwszej potrzeby, „Niedziela” z dnia 22.09.2019 r.

Bauer Z. (2000), Gatunki dziennikarskie, w: Dziennikarstwo i świat mediów, red. Z. Bauer, E. Chudziński, Wydawnictwo Universitas, Kraków, ss. 143-173.

Biskup B. (2012), Prowadzenie kampanii permanentnej w Polsce. Uwagi na temat zjawiska $i$ wykorzystywanych narzędzi, „Studia Politologiczne”, nr 24, ss. $132-148$.

Cinzio K. (2019), Polska pokazała lwi pazur, „Niedziela” z dnia 15.09.2019 r.

Czy Europa przemówi wspólnym głosem? (2019), „Niedziela” z dnia 1.09.2019 r.

Duda A. (2019a), Silni historia i doświadczeniem, „Niedziela” z dnia 1.09.2019 r.

Duda S. (2019b), Trup nieistniejącego Boga, Więź, nr 62.676, ss. 89-103.

Dyda K. (2016), Postulaty legislacyjne Konferencji Episkopatu Polski a obowiazywanie prawa w sumieniu, „Chrześcijaństwo. Świat. Polityka. Zeszyty Społecznej Myśli Kościoła”, nr 20, ss. 101-117. 
Dudkiewicz W. (2019), Szkoły bez eksperymentów, „Niedziela” z dnia 8.09.2019 r.

Dzierżyńska-Mielczarek J. (2016), Tygodnik katolicki „Niedziela” w latach 19812014. Koncepcja wydawnicza i miejsce w polskim systemie medialnym, „Kultura - Media - Teologia”, nr 24, ss. 127-143.

Flis J., Michalak B. (2019), ,, Minimalne” manipulacje, czyli konsekwencje polityczne zmiany struktury okręgów wyborczych w wyborach do sejmu RP, „Decyzje”, nr 31, ss. 73-90.

Fortuna-Sudor M. (2019), Wolni, niezłomni, wierni, „Niedziela” z dnia 18.08.2019 r.

Gadowski W. (2019), Siła mrówki, która świat zmienia..., „Niedziela” z dnia 13.10.2019 r.

Garlicki J. (2010), Komunikowanie polityczne - od kampanii wyborczej do kampanii permanentnej, „Studia Politologiczne”, nr 16, ss. 26-45.

Gembicka A. (2019), Inwestujemy w lokalna Polskę, rozm. przeprowadził A. Stelmasiak, „Niedziela” z dnia 22.09.2019 r.

Grabowski J. (2019a), Jesteś ważny!, „Niedziela” z dnia 13.10.2019 r.

Grabowski J. (2019b), Pamięć i prawda, „Niedziela” z dnia 1.09.2019 r.

Guzek D. (2019), Mediatizing Secular State. Media, Religion and Politics in Contemporary Poland, Wydawnictwo Peter Lang, Berlin.

Jackowski J. (2019), Od tego zależy przyszłość Polski, „Niedziela” z dnia 8.09.2019 r. jk (2019), Cztery lata PAD, „Niedziela” z dnia 18.08.2019 r.

Kasiak M. (2015), Artykuł publicystyczny w świadomości genologicznej dziennikarzy prasowych, „Studia Medioznawcze”, nr 63.4, ss. 83-94.

Kędziora B. (2019), Takie będą Rzeczypospolite, „Niedziela” z dnia 13.10.2019 r.

Klauziński S., Chrzczonowicz M. (2019), Miłosierne kazania abp. Jędraszewskiego: „, Tęczowa zaraza”, ,,Ideologia LGBT zaprzecza godności człowieka”, https:// oko.press/kosciol-lgbt-marsz-bialystok/, 31.12.2019.

Kolczyński M. (2017), Stronniczość mediów w bipolarnym środowisku politycznym. Tygodnik „Polityka” w kampaniach wyborczych 2015 roku, „Polityka i Społeczeństwo", nr 15.1, ss. 33-47.

Kostrzewa J. (2019), Dobre zmiany, „Niedziela” z dnia 15.09.2019 r.

Kotras M. (2018), Narracje i strategie argumentacyjne w dyskursie IV RP jako narzędzia wyznaczania granic wspólnot w polskim społeczeństwie, „Kultura i Społeczeństwo", nr 1, ss. 141-165.

Kowalczyk K. (2012), Partie i ugrupowania parlamentarne wobec Kościoła katolickiego $w$ Polsce $w$ latach 1989-2011, Wydawnictwo Naukowe Uniwersytetu Szczecińskiego, Szczecin.

Kowalczyk K. (2015), Stanowiska polskich partii politycznych wobec religii i Kościoła. Propozycja typologii, „Studia Politicae Universitatis Silesiensis”, nr 15, ss. $156-189$.

Kubicka E. (2019), List otwarty do Prezydenta Gdańska, „Niedziela” z dnia 18.08.2019 r. 
KW Prawo i Sprawiedliwość (2019), Program Prawa i Sprawiedliwości. Polski model państwa dobrobytu, http://pis.org.pl/materialy-do-pobrania, 31.12.2019.

Leśniczak R. (2019), Kategoria negatywizmu a wizerunek prasowy Kościoła katolickiego w kontekście premiery filmu Wojciecha Smarzowskiego „,Kler”. Studium medioznawcze polskich tygodników opinii, „Łódzkie Studia Teologiczne", nr 28.2, ss. 153-172.

Leśniczak R. (2020), Personalizacja wizerunku medialnego instytucjonalnego Kościoła katolickiego $w$ kontekście nadużyć seksualnych niektórych duchownych. Analiza polskich tygodników opinii (2018-2019), „Studia Medioznawcze", 2, ss. 554-568.

Leśniczak R. (2018), Polish Catholic Press and political communication of the Church on the basis of the 2000-2015 presidential election, „Political Preferences", nr 18, ss. 37-56.

Leśniczak R. (2017), Wizerunek prezydenta elekta Andrzeja Dudy w tygodnikach katolickich Gość Niedzielny i Niedziela, „Politeja. Pismo Wydziału Studiów Międzynarodowych i Politycznych Uniwersytetu Jagiellońskiego”, nr 3.48, ss. 299-318.

Mariański J. (2017), Autorytet społeczny Kościoła katolickiego w Polsce w procesie przemian, „Studia Paedagogica Ignatiana”, nr 20.5, ss. 77-106.

Michałek I. (2019), Sukces dziecka = nauka + wychowanie, rozm. przeprowadził A. Tarwid, „Niedziela” z dnia 6.10.2019 r.

Morawiecki M. (2019a), Polski dtugi rok 1939, „Niedziela” z dnia 1.09.2019 r.

Morawiecki M. (2019b), Zależy mi na silnej $i$ wolnej Polsce, rozm. przeprowadzili J. Grabowski, K. Woynarowska, ,Niedziela” z dnia 29.09.2019 r.

Mularczyk A. (2019), Nie wystarczy powiedzieć: Przepraszamy, rozm. przeprowadził P. Rozpiątkowski, „Niedziela” z dnia 22.09.2019 r.

Nosowski Z. (2018), Ból ludzi bólem Kościoła, „Więź”, 61.673, ss. 55-61.

Nosowski Z. (2013), Kościół katolicki w Polsce po 1989 roku. Bliżej społeczeństwa czy bliżej władzy?, w: Dialog wiary z nauka i kultura, red. B. Bogołębska, M. Worsowicz, Wydawnictwo Uniwersytetu Łódzkiego, Łódź, ss. 15-23.

Obajtek D. (2019), Wierze w patriotyzm gospodarczy, rozm. przeprowadzili J. Grabowski, A. Stelmasiak, „Niedziela” z dnia 6.10.2019 r.

Oniszczuk Z. (2011), Mediatyzacja polityki i polityzacja mediów, „Studia Medioznawcze", nr 47.4, ss. 11-22.

Piontkowski D. (2019), Najważniejsi sa uczniowie, rozm. przeprowadził A. Tarwid, „Niedziela” z dnia 25.08.2019 r.

Postanowienie Prezydenta Rzeczypospolitej Polskiej z dnia 25 lutego 2019 r. w sprawie zarządzenia wyborów postów do Parlamentu Europejskiego, Dz. U. 2019, poz. 365, http://prawo.sejm.gov.pl/isap.nsf/download.xsp/ WDU20190000365/O/D20190365.pdf, 31.12.2019.

Postanowienie Prezydenta Rzeczypospolitej Polskiej z dnia 6 sierpnia 2019 r. w sprawie zarządzenia wyborów do Sejmu Rzeczypospolitej Polskiej i do Senatu 
Rzeczypospolitej Polskiej, Dz. U. 2019 poz. 1506, http://prawo.sejm.gov.pl/ isap.nsf/download.xsp/WDU20190001506/O/D20191506.pdf, 31.12.2019.

Rozpiątkowski P. (2019), Katolicka optyka wyborcza, „Niedziela” z dnia 13.10.2019 r. Ryszka C. (2019a), 4 lata prezydentury Andrzeja Dudy, „Niedziela” z dnia 18.08.2019 r.

Ryszka C. (2019b), Kilka myśli przed wyborami, „Niedziela” z dnia 15.09.2019 r.

Ryszka C. (2019c), Z myślą o polskich rodzinach, „Niedziela” z dnia 29.09.2019 r.

Schmidt-Rodziewicz A. (2019), Polacy ze Wschodu wracaja do Ojczyzny, rozm. przeprowadził A. Stelmasiak, „Niedziela” z dnia 29.09.2019 r.

Stelmasiak A. (2019a), Bilans czterech lat rzadu, „Niedziela” z dnia 29.09.2019 r.

Stelmasiak A. (2019b), Polska to ojczyzna bohaterów, „Niedziela” z dnia 8.09.2019 r.

Stelmasiak A. (2019c), Prawicowy spór o aborcje, „Niedziela” z dnia 25.08.2019 r.

Szczegóła L., Kwiatkowski M. (2017), Alternacja systemowa. „Dobra zmiana” $w$ perspektywie socjologii sfery publicznej, „Studia Socjologiczne”, nr 4, ss. 49-71.

wd (2019), Poset na ambonie, „Niedziela” z dnia 1.09.2019 r.

Wołochowicz M. (2019), Przejęcie odpowiedzialności, rozm. przeprowadził D. Krawczykowski, „Niedziela” z dnia 13.10.2019 r.

Wrześniewska M. (2017), Polityka w prasie - analiza prasoznawcza czasopisma „Niedziela” za rok 2016, w: Polityka i politycy w prasie XX i XXI wieku. Prasa organizacji politycznych, red. M. Dajnowicz, A. Miodowski, Wydawnictwo HUMANICA Instytut Studiów Kobiecych, Białystok, ss. 337-349.

Wysogląd P. (2019), Bo jestem obywatelem, „Niedziela” z dnia 13.10.2019 r.

Zaręba A. (2016), Permanent campaign in Poland - causes, elements, importance, „Political Preferences”, nr 13, ss. 97-113.

Żaryn J. (2019), Brygada w marszu, ,Niedziela” z dnia 18.08.2019 r.

\section{Did the Catholic weekly Niedziela support the Law and Justice party in the 2019 parliamentary campaign? Media studies research}

\section{Summary}

The purpose of the article is to verify whether the Catholic weekly Niedziela was involved in the 2019 parliamentary campaign in Poland as a participant in the process of political communication. The basic research method applied is quantitative and qualitative content analysis. The method of analysis and synthesis, as well as context analysis of press discourse, were also used as auxiliary methods. The Catholic weekly did indeed support Law and Justice. The statements of right-wing politicians were published by the editors of Niedziela with approval and sympathy. The failure to give voice to opposition politicians in the political discourse proves the bias of the weekly 
and the prevalence of "the one and only" direction of foreign, economic or historical policy, namely that proposed by Law and Justice.

Key words: Catholic weekly Niedziela; Law and Justice party; parliamentary campaign; political communication 